\title{
Rigorous Analysis of Available Data from Cerro Prieto and Las Tres Virgenes Geothermal Fields with Calculations for Expanded Electricity Generation
}

\author{
Rosa María Prol-Ledesma, ${ }^{1,3}$ Claudia Arango-Galván, ${ }^{1}$ \\ and Marco-Antonio Torres-Vera ${ }^{2}$
}

Received 27 December 2015; accepted 7 March 2016

Published online: 21 March 2016

\begin{abstract}
Changes in legislation have opened the Mexican geothermal resources for exploitation to private companies; therefore the evaluation of the known geothermal areas has a high priority to plan further exploitation and possibly the expansion of the well fields. The calculation of the remaining productivity of geothermal fields currently in exploitation can be achieved with less uncertainty using the parameters obtained from production and injection wells, as well as the production efficiency of the installed plants. No information about previous volumetric evaluation is available for the fields presently being exploited, and there is the possibility that they may support an increase in their energy output or extend further their production life. The most widely used calculation technique is the USGS volumetric method that requires the knowledge of parameters that can be measured only after exploitation started. Heat in place-volumetric evaluation was undertaken for two fields in Mexico: Cerro Prieto and the Las Tres Vírgenes geothermal fields, using all information obtained by exploration surveys and exploitation drilling. The obtained values allow planning a possible expansion of the fields based on their estimated mean potential output that is 1397 MWe for Cerro Prieto and 48 MWe for Las Tres Vírgenes compared to the presently installed capacity of $580 \mathrm{MWe}$.
\end{abstract}

KEY WORDS: Volumetric heat in place method, Cerro Prieto, Las Tres Vírgenes, Mexico, Baja California, Geothermal resources evaluation.

\section{INTRODUCTION}

Geothermal energy exploitation in México started in the 1950s with the commissioning of the $3 \mathrm{MWe}$ Pathé geothermal plant, and the Cerro Prieto geothermal field started producing electricity in 1973. Since then, México has been one of the leading producers of geothermal energy with four fields that rep-

\footnotetext{
${ }^{1}$ Instituto de Geofísica, Universidad Nacional Autónoma de México, 04510 Mexico, D.F., Mexico.

${ }^{2}$ APEC, I.A.P., Vicente García Torres 46, 04030 Mexico, D.F., Mexico.

${ }^{3}$ To whom correspondence should be addressed; e-mail: prol@unam.mx
}

resent almost $3 \%$ of the total electricity production in the country: Cerro Prieto, Las Tres Vírgenes, Los Azufres, and Los Humeros (Fig. 1). All the geothermal energy of Mexico used to be produced by the stateowned company Federal Commission of Electricity (CFE_Comisión Federal de Electricidad), but recent changes in legislation allow private companies to produce and sell electricity, and it has been announced that more of $90 \%$ of the probable geothermal resources in Mexico are now open for private investment. These new regulations are expected to promote investment in geothermal energy exploitation and utilization, and a key factor for this to happen is a reliable evaluation of Mexico's geothermal resources. 


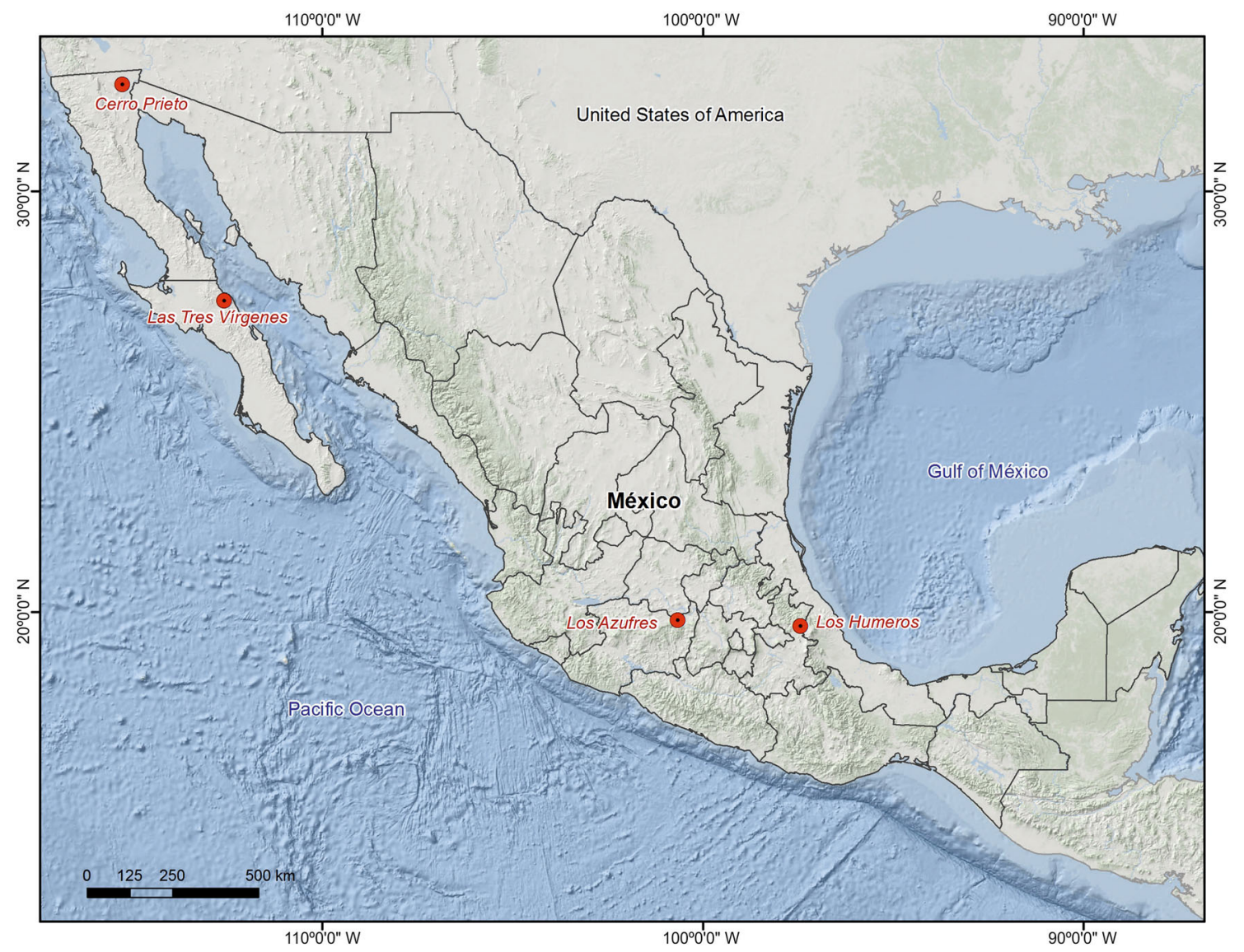

Figure 1. Location of the four geothermal fields currently in exploitation in Mexico.

Numerous evaluations of Mexico's electrical potential have been conducted since the early years of geothermal exploration; the results vary in several orders of magnitude (Table 1). The most recent national evaluation produced by CFE (Ordaz-Méndez et al. 2011) defines total geothermal reserves of almost 10,000 MWe for 1380 geothermal areas; more than $90 \%$ of which lack geophysical studies that would allow calculation of the reservoir volume. The most recent evaluation was published by GutiérrezNegrín (2012) based on data from Ordaz-Méndez et al. (2011) and Hiriart et al. (2011) with a total of 1940 MWe.

Traditionally, estimation of the energy potential of a hydrothermal system has been performed using the "heat in place" methodology proposed by Muffler and Cataldi (1978). However, recently more strict requirements have been established and geothermal resources must be assessed using the presently accepted methodology (AGEA-AGEG 2010; van Wees et al. 2013). Most published evalu- ations of the geothermal resources in México do not abide by any of the presently accepted codes, as most of them lack geophysical surveys and exploration drilling that provide information on the reservoir parameters. Therefore, the planning of future development of Mexican geothermal fields requires intense work to gather required information. For instance, numerous geothermal systems have been studied in the Baja California Peninsula and preliminary evaluations indicate possible resources of more than $400 \mathrm{MWe}$ (Arango-Galván et al. 2015) in addition to the $580 \mathrm{MWe}$ installed in the Cerro Prieto and Las Tres Vírgenes geothermal fields (Flores-Armenta et al. 2014).

Knowledge of the estimated capacity of a geothermal field is vital in planning for further development. The geothermal potential of Mexico offers immense possibilities for investment in geothermal energy exploitation in new geothermal fields or developing joint ventures in fields already in exploitation that could be suitable for further 
Table 1. Evaluation of the Geothermal Resources in México, Published by Different Institutions/Authors Since the Start of Geothermal Exploitation in the Country (Alonso 1975, 1985; Mercado et al. 1982, 1985; Iglesias and Torres 2003, 2009; Ordaz-Méndez et al. 2011; Hiriart et al. 2011; Gutiérrez-Negrín 2012; Arango-Galván et al. 2015)

\begin{tabular}{|c|c|c|c|c|c|}
\hline Author (year) & $\begin{array}{l}\text { Proved } \\
\text { Reserves }\end{array}$ & $\begin{array}{l}\text { Probable } \\
\text { Reserves }\end{array}$ & $\begin{array}{l}\text { Possible } \\
\text { Reserves }\end{array}$ & MWe (Total) & Remarks \\
\hline Alonso (1975) & & & & 4000 & \\
\hline Mercado (1976) & & & & 13,110 & \\
\hline Alonso (1985) & 1340 & 4600 & 6000 & 11,940 & \\
\hline Mercado et al. (1985) & & & & 45,815 & $\begin{array}{l}\text { Hydrothermal manifestations with } \\
\text { temperature in the range } 125-135^{\circ} \mathrm{C}\end{array}$ \\
\hline Iglesias and Torres (2003) & & & & $2.2610^{10} \mathrm{MWth}$ & $\begin{array}{l}\text { (276 geothermal areas with } T \text { between } \\
60 \text { and } 180^{\circ} \mathrm{C} \text { ) }\end{array}$ \\
\hline Iglesias and Torres (2009) & & & & $33.810^{10}$ MWth & $\begin{array}{l}918 \text { zones with } T \leq 200^{\circ} \mathrm{C}(1631 \\
\quad \text { manifestations })\end{array}$ \\
\hline Ordaz-Méndez et al. (2011) & 186 & 2077 & 7423 & 9686 & $\begin{array}{l}1380 \text { geothermal manifestations and } \\
\text { geothermal fields }\end{array}$ \\
\hline Hiriart et al. (2011) & & & & 751 & $\begin{array}{l}\text { Volumetric evaluation of } 20 \text { geothermal } \\
\text { areas (with and without geophysical data) }\end{array}$ \\
\hline Gutiérrez-Negrín (2012) & 75 & 655 & 1210 & 2310 & $\begin{array}{l}\text { Based on Ordaz et al. Ordaz-Méndez et al. } \\
\text { (2011) and Hiriart et al. (2011) }\end{array}$ \\
\hline Arango-Galván et al. (2015) & & & & $>400 \mathrm{MWe}$ & Only for Baja California Peninsula \\
\hline
\end{tabular}

development to increase production. Consequently, it is important to refine the estimation for future production in producing fields like Cerro Prieto and Las Tres Vírgenes based on information gathered during their exploitation history. A similar approach was applied to compare previous evaluations by Turner (1969) and Bodvarsson and Bolton (1971) with the actual production of the Ahuachapán Geothermal Field by McNitt (1978), as well as in some geothermal fields in the Great Basin (Williams 2014) and in the Sumikawa geothermal field (Garg and Combs 2015).

In this paper we present most available data from the Cerro Prieto and Las Tres Vírgenes geothermal fields, which have been producing electricity for many years, as in the case of Cerro Prieto more than 30 years. Production in both fields has remained stagnant or even decreased in the last few years, and the possibility of increasing energy production would be appealing for $\mathrm{CFE}$ and private investors. The analysis of the electricity generation capacity may be useful in planning for further development of both fields, and to compare previous resource evaluation with present production and future possibilities. In the analysis of the potential of both geothermal fields, we included data of surface manifestations, pre- and post-exploitation geophysical surveys, as well as well data to improve the results of the calculated resource potential.

\section{GEOTHERMAL RESOURCE ASSESSMENT}

There are several methods to estimate the amount of energy that can be extracted from a geothermal reservoir but the most widely used is the volumetric-probabilistic method utilized by the USGS, which evaluates the heat content in the rocks in the reservoir and the geothermal fluid (Muffler and Cataldi 1978; Muffler 1979; Williams et al. 2008; Garg and Combs 2010, 2015; Williams 2014). This method requires knowledge of the main reservoir parameters: temperature, rock specific heat, depth, effective porosity, permeability, as well as the fluid circulation model including recharge, predominant phase in the geothermal fluid, and the production methodology including extraction technique, drilling cost, efficiency of electricity production, investment cost, energy cost, investment risk, and environmental restrictions. The volumetric method includes several parameters, such as the reference temperature that are critical for the energy output. In a recent paper, Garg and Combs (2015) demonstrated that the reference temperature traditionally used in the volumetric method (i.e., ambient or condenser temperature), yields estimates that are too optimistic, as the reference temperature should be taken as the abandonment temperature, which would be the saturation temperature corresponding to the separation pressure. This value may reduce the 
estimated energy output of the system by more than 50\% (Garg and Combs 2015).

Generally, the application of the volumetric method in early exploration stages relies upon the estimated values of some parameters based on the results of geochemical and geophysical studies. However, continuous upgrade of these calculations should be conducted using the data acquired during each phase of the reservoir exploitation. This would provide fine tuning of the estimation of the reservoir electrical capacity by assigning more realistic values to the recoverable heat and the production efficiency and load factor. Williams (2014) demonstrated that comparison of results of the volumetric method with actual production in some fields in the Great Basin validates this method, provided it is properly calibrated with field measurements.

The common strategy for evaluation of geothermal areas includes estimation of reservoir temperature from geothermometer calculations, assessment of volume reservoir based on geophysical surveys, and average values calculated for known areas are assigned to the rest of the parameters. In the case of geothermal fields that are already in exploitation, data from exploitation wells are included in order to obtain better estimates, especially for the thermal recovery factor that is the critical parameter in the volumetric method. The thermal recovery factor can be known only after drilling data define parameters like permeability and porosity. This factor is generally assumed to be in the range from 0 to 0.20 (Garg and Combs 2010, 2015). Williams (2014) suggests that the range of the thermal recovery factor for sediment-hosted reservoirs, with higher permeability than those in volcanic rocks, is slightly higher from 0.10 to 0.25 and for fractured reservoirs the range should be from 0.05 to 0.20 .

\section{CERRO PRIETO GEOTHERMAL FIELD (CPGF)}

The CPGF is located on the Colorado River delta plain where the Cerro Prieto volcano stands out with a height of 225 masl (Fig. 1). The reservoir is contained within the thick sediment cover deposited from Pliocene to Pleistocene (Halfman et al. 1984). The regional tectonics of Baja California is strongly related to the geodynamic setting of the Gulf of California. The opening of the Gulf of California and subsequent oceanic extension are the result of a local reorganization of the plate movement. In the northern part of the peninsula, active faults associated with geothermal areas (Cerro Prieto and Ensenada) have an orientation $\mathrm{N} 40^{\circ} \mathrm{W}$ and $\mathrm{N} 70^{\circ} \mathrm{W}$ (Cruz-Castillo 2002). The fault systems in the Cerro Prieto area have NESW (Morelia, Hidalgo, Pátzcuaro and Delta faults) and NW-SE (Cerro Prieto, Imperial and Michoacán faults) directions; the latter system presents high volcanic and seismic activity and a close relation with hydrothermal manifestations (Puente and DeLa-Peña 1979).

The Cerro Prieto volcano is located approximately $35 \mathrm{~km}$ south of Mexicali. The dacitic Cerro Prieto lavas are the only surface manifestation of volcanic activity in the surroundings of the CPGF. The volcanic activity has been dated by paleomagnetic evidence between 100,000 and 10,000 years (De Boer 1980). The volcanic rocks in Cerro Prieto are grouped in four types (Quintanilla-Montoya and Suárez-Vidal 1996): (a) basalt, (b) basaltic andesite, (c) andesite, and (d) dacite.

Thermal manifestations are mud pools, hot springs, and hot wells; additionally, most irrigation wells have temperatures ranging from 23 to $47^{\circ} \mathrm{C}$ (Portugal et al. 2005a). Geothermal water from hot springs and exploration/observation wells is sodium chloride type. Water samples from hot springs show partial equilibrium yield geothermometer temperatures in the range from 206 to $253^{\circ} \mathrm{C}$, and the reservoir temperature calculated with geothermometers for well samples that are in full equilibrium is above $300^{\circ} \mathrm{C}$ (Portugal et al. 2005a). Measured temperatures in the exploration and production wells are between 280 and $350^{\circ} \mathrm{C}$ (Gutiérrez-Puente and Rodríguez 2000). All production strata are contained in sedimentary rocks.

The first geophysical surveys (Razo and Fonseca 1978), focused on the geothermal potential evaluation of the Cerro Prieto and Imperial faults, defined a typical pull-apart basin structure for the valley (Lira 2005). Further resistivity surveys (Razo and Arellano 1978; Díaz and Arellano 1979) detected three different geo-electrical units: the first one from 400 to $900 \mathrm{~m}$ depth with a resistivity value of $30 \Omega \mathrm{m}$, a second more conductive horizon from 1300 to $3000 \mathrm{~m}$ with a resistivity value of $6 \Omega \mathrm{m}$, and the deepest one (depth $>3000 \mathrm{~m}$ ) with resistivity values varying between 30 and $150 \Omega \mathrm{m}$. Structures revealed by the geophysical studies in the CPGF are presented in Figure 2. These results were used in the early stages of development to determine the location of the reservoir and for delineation of the production area. A subsequent survey by Castillo et al. 

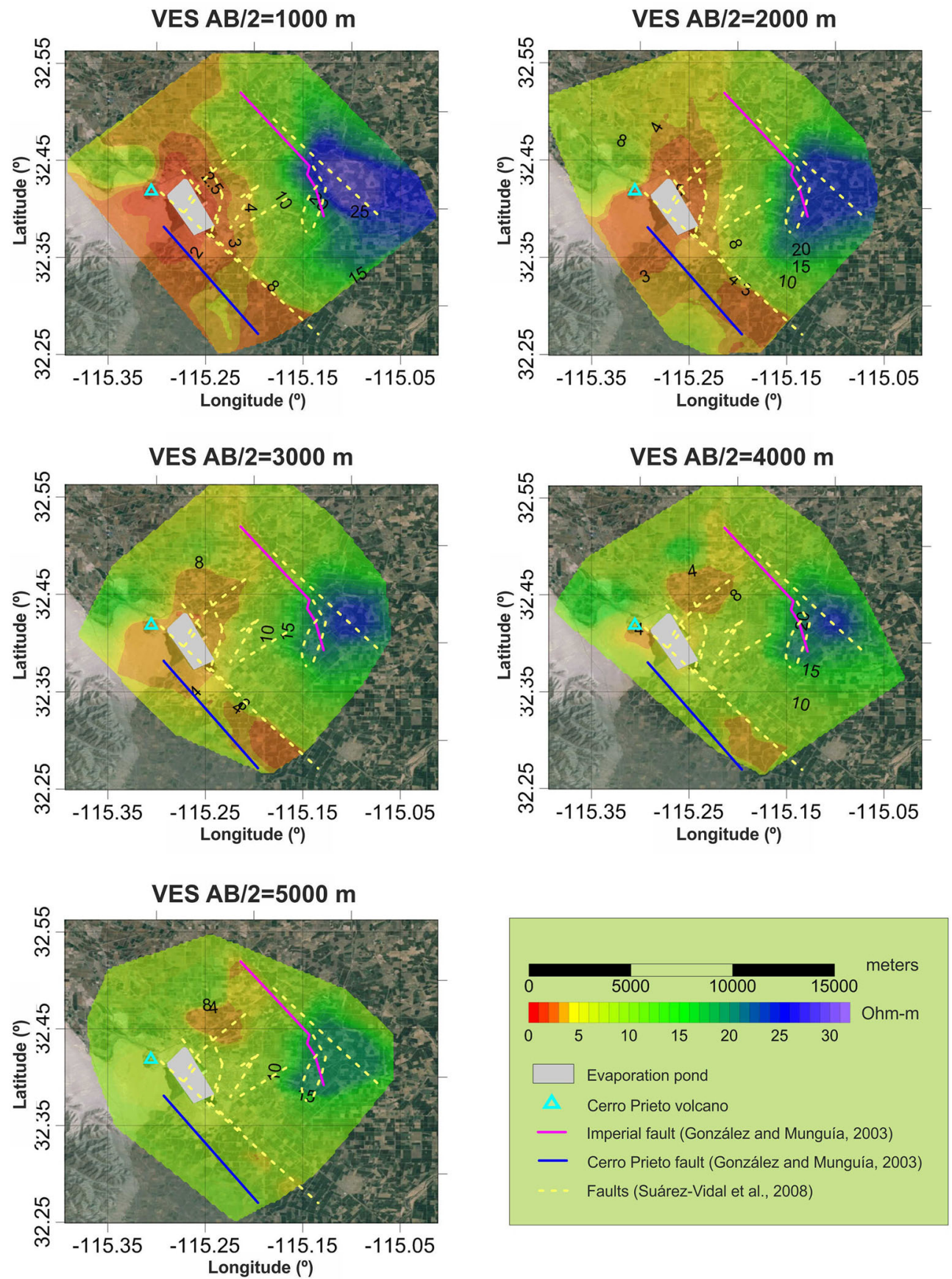

Figure 2. Structures defined by geophysical studies in the CPGF (after González and Munguía 2003; Suárez-Vidal et al. 2008; CFE 1984).

(1981) estimated that the reservoir maximum thickness was about $2 \mathrm{~km}$ and its area was in the interval between 18 and $30 \mathrm{~km}^{2}$ based on high conductivity anomalies. These estimations agree with the results of a 1979-1980 dipole-dipole survey (Wilt et al. 1984). A conceptual model of the field based on well data and hydrogeological parameters is shown in Figure 3. 


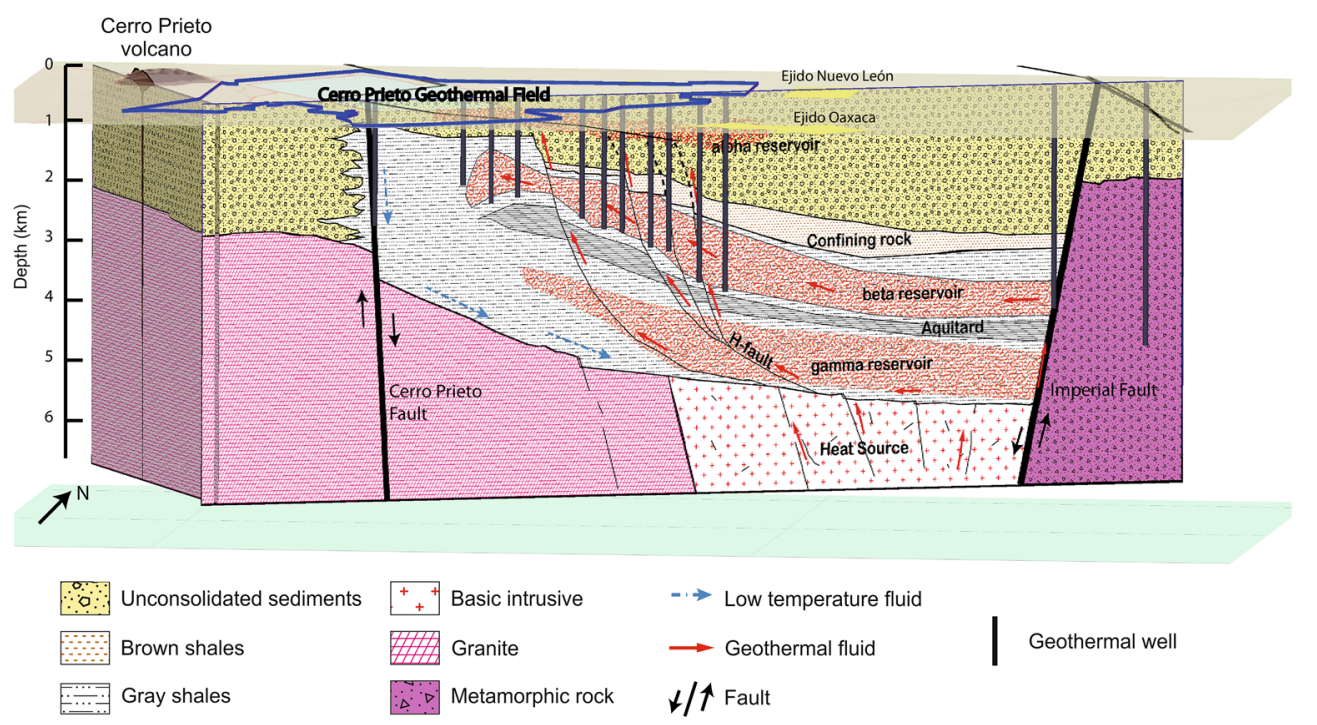

Figure 3. Conceptual model of the CPGF (after Lippmann et al. 1991; Lira 2005).

\section{CPGF Production History}

The CPGF is the largest producer of geothermal energy in México. In 2005 it produced $50 \%$ of the electricity $(720 \mathrm{MWe})$ required in the NW part of the country (Portugal et al. 2005a). The long exploitation history of Cerro Prieto has been summarized by Gutiérrez-Puente and Rodríguez (2000), Lippmann et al. (2004), and DiPippo (2012).

Presently, the field is divided into four areas: CP-I (Cerro Prieto I), CP-II (Cerro Prieto II), CPIII (Cerro Prieto III), and CP-IV (Cerro Prieto IV). CP-1 was the first part of the field to be exploited in 1973. The CPGF reservoir has been divided into three sections: alpha, beta, and gamma. The alpha reservoir is restricted to the western part of the field; it is the shallowest one (depths are between 1000 and $1500 \mathrm{~m}$; Gutiérrez-Puente and Rodríguez 2000). The beta reservoir is deeper (depths ranging from 1500 to $2700 \mathrm{~m}$ ) with a minimum area of $15 \mathrm{~km}^{2}$ (Portugal et al. 2005b); its temperature is much higher than that of the alpha reservoir and its top is defined by the upper limit of the silica-epidote continuous occurrence (Cobo 1979). There are no reports of exploitation of the gamma reservoir (Izquierdo et al. 2001), which is the deepest and hottest portion of the reservoir contained in the sand unit found below $3300 \mathrm{~m}$ depth with temperatures probably above $350^{\circ} \mathrm{C}$ (Lippmann et al. 1991). It has been hypothesized that temperatures above $350^{\circ} \mathrm{C}$ predominate at least over an area of approximately $5 \mathrm{~km}^{2}$ in the Nuevo Leon section of the field (Cas- tillo et al. 1981) that would be the minimum value of the gamma reservoir extent. The parameters of the deepest reservoir were estimated using completion and reservoir data for the deep well M-201 $($ depth $=3820 \mathrm{~m})$ to simulate pseudo-transient flowing conditions (García et al. 1999): pressure -321 bar; temperature $-350^{\circ} \mathrm{C}$; porosity -0.15 ; transmissivity-8 Darcy-m; reservoir thickness-300 m; rock thermal conductivity-1.7 W/ $\mathrm{m} \mathrm{K}$; rock density-2500 kg/m .

Currently, the CPGF production is generated by 9 units (Flores-Armenta et al. 2014)-four $110 \mathrm{MW}$ double-flash, four single-flash of $25 \mathrm{MW}$ each, and one $30 \mathrm{MW}$ single-flash, low pressure-amounting a total of $570 \mathrm{MWe}$, as the four 37.5 MW units in CP-I were decommissioned in 2012. The power units produced $3996 \mathrm{GWh}$ in 2013 at an annual capacity factor of $78 \%$ with an annual average consumption of 8.5 tons of steam per MWh (Flores-Armenta et al. 2014), while in 2011 the capacity factor was $72 \%$ (Flores-Armenta 2012).

Based on early simulations of the first three exploitation stages for a period of 20 years, the pressure could at the end of this period be maintained close to 100 bars and the reservoir enthalpy would decrease to $1030 \mathrm{~kJ} / \mathrm{Kg}$, corresponding to a liquid water temperature value of $237^{\circ} \mathrm{C}$ (Castañeda et al. 1983). However, more recent numerical models (Antunez et al. 1991; Butler et al. 2000) agree that the most reliable source for long-term production, in order to ensure a 30-year long generation of at least $600-700 \mathrm{MW}$, would be the beta reservoir 
(deeper than $1600 \mathrm{~m}$ ). This statement has proved to be realistic as most wells in the alpha reservoir have now been shut. Some authors (e.g., Lippmann et al. 2004) stress the fact that large deep parts of the reservoir still remain unexploited and they could support future expansion of the field given the high temperatures expected.

\section{Parameters for Volumetric Evaluation of the CPGF}

Available data from the CPGF that can be used as input to volumetric evaluation are presented in Table 2. The only reservoir section that currently has enough information to be considered for a consistent volumetric evaluation is the beta reservoir. It extends over most of the well field at depths below $1600 \mathrm{~m}$ for at least $15 \mathrm{~km}^{2}$ (Portugal et al. 2005b) and has an estimated minimum thickness of $1600 \mathrm{~m}$ (Butler et al. 2000). The area that bounds the producing area of the CPGF as reported by DOE-CFE (1982; in Castañeda et al. 1983) is $19.5 \mathrm{~km}^{2}$, liquid water was the dominant phase in the reservoir but exploitation induced local boiling and the presence of small two phase areas (Grant et al. 1981). However, the reservoir remained liquid dominated. Castillo et al. (1981) reported that the maximum thickness of the reservoir is about $2 \mathrm{~km}$ and the maximum value for the area is $30 \mathrm{~km}^{2}$ (Castillo et al. 1981) on the basis of the observed high electrical conductivity anomalies.

The maximum temperature measured in the eastern part of the field is $350^{\circ} \mathrm{C}$ (Lippmann et al. 1997). Exploitation data from Cerro Prieto for 28 years indicate minimum and maximum temperatures of 280 and $350^{\circ} \mathrm{C}$, respectively (GutiérrezPuente and Rodríguez 2000). Production data indicate a mean temperature of $320^{\circ} \mathrm{C}$ (DiPippo 2012).

Feeding hot fluids $\left(T>350^{\circ} \mathrm{C}\right)$ from the deepest reservoir (below 3300 m; Lippmann et al. 1991) have helped to keep the high temperatures of the beta reservoir. Therefore, even after more than 30 years of continuous exploitation, the beta reservoir was still keeping a maximum temperature close to $350^{\circ} \mathrm{C}$ (Gutiérrez-Puente and Rodríguez 2000). This hot recharge with the high porosity and transmissivity detected for the beta reservoir (Butler et al. 2000) validate the use of a recovery factor in the range of $0.10-0.25$ for the CPGF beta reservoir (Garg and Combs 2010; 2015; Williams 2014).

The inlet saturation temperature of the low pressure turbine in CP-II and CP-III is approxi- mately $135^{\circ} \mathrm{C}$ and the utilization efficiency is $49.3 \%$ (DiPippo 2012). This temperature can be assumed as the abandonment temperature for the volumetric evaluation (Table 2).

In addition to the evaluation of the beta reservoir, we attempted to estimate the minimum potential of the gamma reservoir using the minimum values for the reservoir parameters suggested by different authors and production parameters of $\mathrm{CP}$ IV (Table 2). The future exploitation of this section of the reservoir would be an important contribution to the energy output of the CPGF.

\section{LAS TRES VÍRGENES GEOTHERMAL FIELD (LVTGF)}

The LTVGF is located in the central part of the Baja California Peninsula in a volcanic complex that includes three volcanic systems (Fig. 4): La Reforma Caldera to the east, Aguajito complex to the north, and the Las Tres Vírgenes volcanoes to the southwest. These structures were emplaced along a NWSE fault system between 3.5 and $0.8 \mathrm{Ma}$ (LópezHernández et al. 1989) for La Reforma Caldera; between 0.7 and $0.45 \mathrm{Ma}$ for the Aguajito complex (López-Hernández et al. 1993), and from 0.4 Ma to the present for Las Tres Vírgenes volcanoes (LópezHernández et al. 1995).

Three volcanoes form the Las Tres Vírgenes complex. The oldest is called El Viejo (0.44 Ma) and the youngest is located to the south (La Virgen), which is still active (Fig. 4). The composition of these volcanoes is mostly dacitic to the north but shifts to basaltic to the south (López-Hernández et al. 1995). The volcanic complex is located in a Plio-Quaternary depression that is the western border of a NW-SE regional transform fault related to the opening of the Gulf of California (López-Hernández et al. 1995). The NW-SE Las Víboras fault system is the one related with the hydrothermal activity.

Exploration studies were conducted in a $250 \mathrm{~km}^{2}$ area and defined an extension of the geothermal field of $57 \mathrm{~km}^{2}$ (García-Cruz and Ramírez 2000). Numerous hydrothermal manifestations occur in the field and chemical compositions include: sodium chloride, sulfate, and bicarbonate water (Portugal et al. 2000; Tello et al. 2005; Viggiano-Guerra et al. 2009; Birkle et al. 2010). Geothermal water from the production wells is sodium chloride type and presents full equilibrium 
Table 2. Parameters for Calculation of Production Potential of Cerro Prieto and Las Tres Vírgenes Geothermal Fields, Obtained from Available Information

\begin{tabular}{|c|c|c|c|}
\hline & Cerro Prieto (Beta Reservoir) & Cerro Prieto (Gamma Reservoir) & Tres Virgenes \\
\hline \multicolumn{4}{|c|}{ Area $\left(\mathrm{m}^{2}\right)$} \\
\hline Min. & $15,000,000^{\mathrm{a}}$ & $5,000,000^{\mathrm{c}}$ & $6,000,000^{\mathrm{k}}$ \\
\hline Mean & $19,500,000^{\mathrm{b}}$ & & \\
\hline Max. & $30,000,000^{\mathrm{c}}$ & & $30,000,000^{1}$ \\
\hline \multicolumn{4}{|c|}{ Thickness (m) } \\
\hline Min. & $1600^{\mathrm{d}}$ & $300^{\mathrm{i}}$ & $300^{\mathrm{k}}$ \\
\hline Max. & $2000^{c}$ & & $1300^{\mathrm{m}}$ \\
\hline \multicolumn{4}{|c|}{ Temperature $\left({ }^{\circ} \mathrm{C}\right)$} \\
\hline Min. & $280^{\mathrm{e}}$ & $350^{\mathrm{j}}$ & $225^{\mathrm{m}}$ \\
\hline Mean & $320^{\mathrm{f}}$ & & $275^{\mathrm{m}}$ \\
\hline Max. & $350^{\mathrm{e}}$ & & $300^{\mathrm{n}}$ \\
\hline \multicolumn{4}{|c|}{ Abandonment temperature (at Psep) } \\
\hline & $135^{\mathrm{f}}$ & $135^{\mathrm{f}}$ & $150^{\mathrm{k}}$ \\
\hline \multicolumn{4}{|c|}{ Recovery factor ${ }^{\mathrm{g}}$} \\
\hline Min. & 0.10 & & 0.05 \\
\hline Max. & 0.25 & & 0.20 \\
\hline \multicolumn{4}{|c|}{ Utilization efficiency (\%) } \\
\hline & $49.3^{\mathrm{f}}$ & $49.3^{\mathrm{f}}$ & $13^{\mathrm{o}}$ \\
\hline \multicolumn{4}{|c|}{ Average plant capacity factor (\%) } \\
\hline & $78^{\mathrm{h}}$ & $78^{\mathrm{h}}$ & $56^{\mathrm{h}}$ \\
\hline
\end{tabular}

Data from: ${ }^{\mathrm{a} P o r t u g a l}$ et al. (2005b); ${ }^{\mathrm{b}}$ Castañeda et al. (1983); ${ }^{\mathrm{c} C a s t i l l o ~ e t ~ a l . ~(1981) ; ~}{ }^{\mathrm{d}}$ Butler et al. (2000); ${ }^{\mathrm{e}}$ Gutiérrez-Puente and Rodríguez

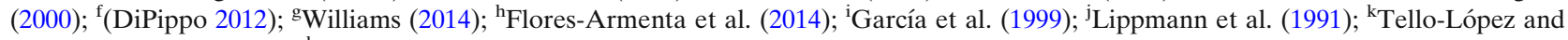

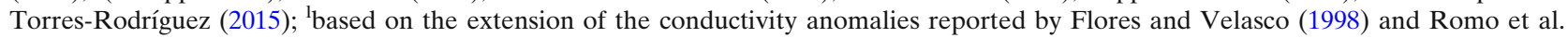
(2000); ${ }^{\mathrm{m}}$ García-Cruz and Ramírez (2000); ${ }^{\mathrm{n} P o r t u g a l ~ e t ~ a l . ~(2000) ; ~}{ }^{\circ}$ based on calculations from Zarrouk and Moon (2014).

with a calculated reservoir temperature around $300^{\circ} \mathrm{C}$ and the isotopic composition indicates a magmatic contribution of at least 30\% (Portugal et al. 2000).

Permeability in the field is secondary and associated with the NW-SE and N-S faults. It varies from 0.3 to $3.0 \mathrm{mD}$, with an effective porosity from 0.4 to $5 \%$ (Contreras and García 1998). The national water authority (CONAGUA) has evaluated 4.7 $\mathrm{hm}^{3} /$ year as the mean annual recharge of the local aquifer (CONAGUA 2011) and the average annual rainfall amounts to $62 \mathrm{~mm}$ with maximum values of $150 \mathrm{~mm}$ at the summit of La Virgen and El Azufre volcanoes (Portugal et al. 2000). Climate, hydrogeological conditions, and age data of the geothermal water suggest that modern water recharge might be practically absent (Birkle et al. 2010). However, hydrogeological studies have not yet provided enough evidence to establish the nature and volume of the field recharge (Birkle et al. 2010).

Geophysical information for the Las Tres Virgenes geothermal field is abundant. A review of the reported surveys is shown in Figure 5. The earliest results obtained by Razo Montiel (1984) indicate the presence of a conductive body (between 3 and $8 \Omega \mathrm{m}$ ) at a depth of $1900 \mathrm{~m}$. Gravity and magnetic data show that the main structures have a direction NE-SW in Volcán El Azufre, Volcán Partido, and Sierra El Aguajito, and NW$\mathrm{SE}$ in El Azufre Canyon. Minimum magnetic values are associated with hydrothermal alteration in the area of El Azufre, La Biznaga, and Las Víboras. The most recent geoelectric studies (Flores and Velasco 1998; Romo et al. 2000) showed that the most interesting area for geothermal exploration is located along El Azufre Canyon that represents the border between the volcanic complex Las Tres Vírgenes and El Aguajito Caldera (Fig. 5). Both reports provide results that indicate the presence of conductive bodies at approximate depths of 1500 and $12,000 \mathrm{~m}$. The thickness of the shallow conductive layer observed in those studies varies from 0.5 to $3 \mathrm{~km}$ and has an area of at least $30 \mathrm{~km}^{2}$. However, very low resistivity values could be partly related to the presence of a clay layer. This would cause overestimation of the reservoir volume. Therefore, the area of resistivity anomalies $\left(30 \mathrm{~km}^{2}\right)$ should be considered as a maximum value for the reservoir extension. A conceptual model of the Las Tres Vírgenes field based on compiled geological and geophysical data is presented in Figure 6. 

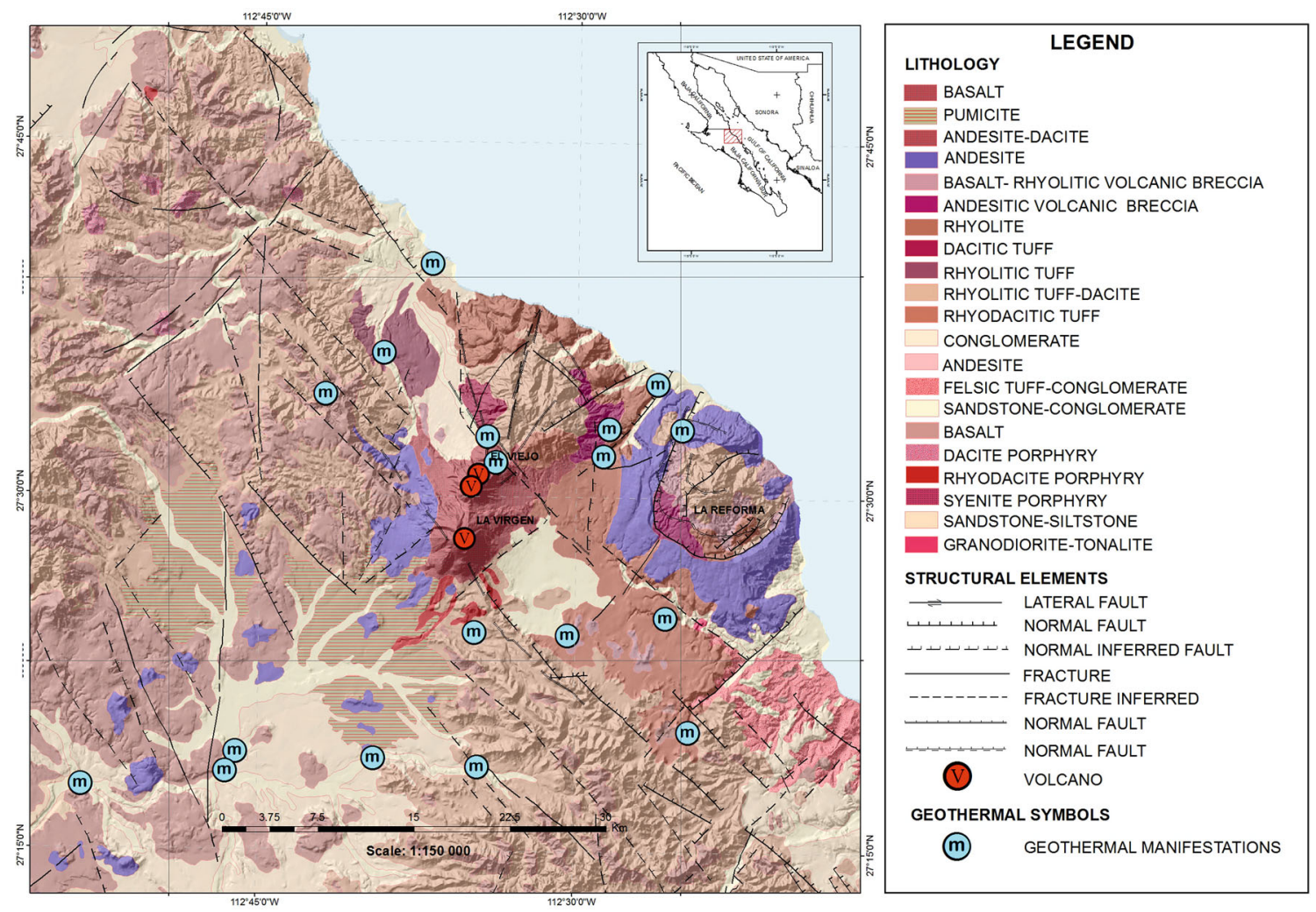

Figure 4. Surface geology and main structures in the LTVGF (after Wong et al. 2001).

\section{Production History and Parameters for Volumetric Evaluation}

Exploration in the LTVGF started in 1986 and production started in 2001. Currently, it has an installed capacity of $10 \mathrm{MWe}$ with two back-pressure 5 MW generation units at an annual mean capacity factor of 56\% in 2013 (Flores-Armenta et al. 2014).

The initial evaluation of the field for exploitation assessed an area of $90 \mathrm{~km}^{2}$ and $1500 \mathrm{~m}$ thickness for the reservoir that is contained in the granodiorite horizon at a depth of more than $1000 \mathrm{~m}$ (Flores-Armenta and Jaimes-Maldonado 2001). However, a recent evaluation of the reservoir reports an area of $6 \mathrm{~km}^{2}$ by considering only the producing wells location (Tello-López and TorresRodríguez 2015); these authors estimate a reservoir thickness of $300 \mathrm{~m}$ based on the main permeable zone. García-Cruz and Ramírez (2000) proposed $1300 \mathrm{~m}$ as the thickness of the reservoir using observations during drilling (circulation loss, alteration intensity, and temperature profiles). Feeding zones have been identified at different depths in the wells (Barragán et al. 2010).

After almost 15 years of exploitation, the uncertainty in the reservoir parameters is large: 6$90 \mathrm{~km}^{2}$ for the area and from 0.3 to $1.5 \mathrm{~km}$ for the thickness. Therefore, we use the values that are supported by drilling or geophysical evidence and designate the minimum and maximum values for the area and the thickness as 6 and $30 \mathrm{~km}^{2}$, and 0.3 and $1.3 \mathrm{~km}$, respectively.

The lowest temperature reported is $225^{\circ} \mathrm{C}$ in the northern part of the field, which is not presently in exploitation (Torres-Rodríguez and Sánchez-Velasco 1995). The most recent report for temperature and pressure is $275^{\circ} \mathrm{C}$ and 144 bars, respectively, in producing wells in the southern part of the field (Tello-López and Torres-Rodríguez 2015). However, the highest temperature calculated for the reservoir is $300^{\circ} \mathrm{C}$ (Portugal et al. 2000). Abandonment temperature is considered to be the saturation temperature at the installed plants $-150^{\circ} \mathrm{C}$ (TelloLópez and Torres-Rodríguez 2015). 

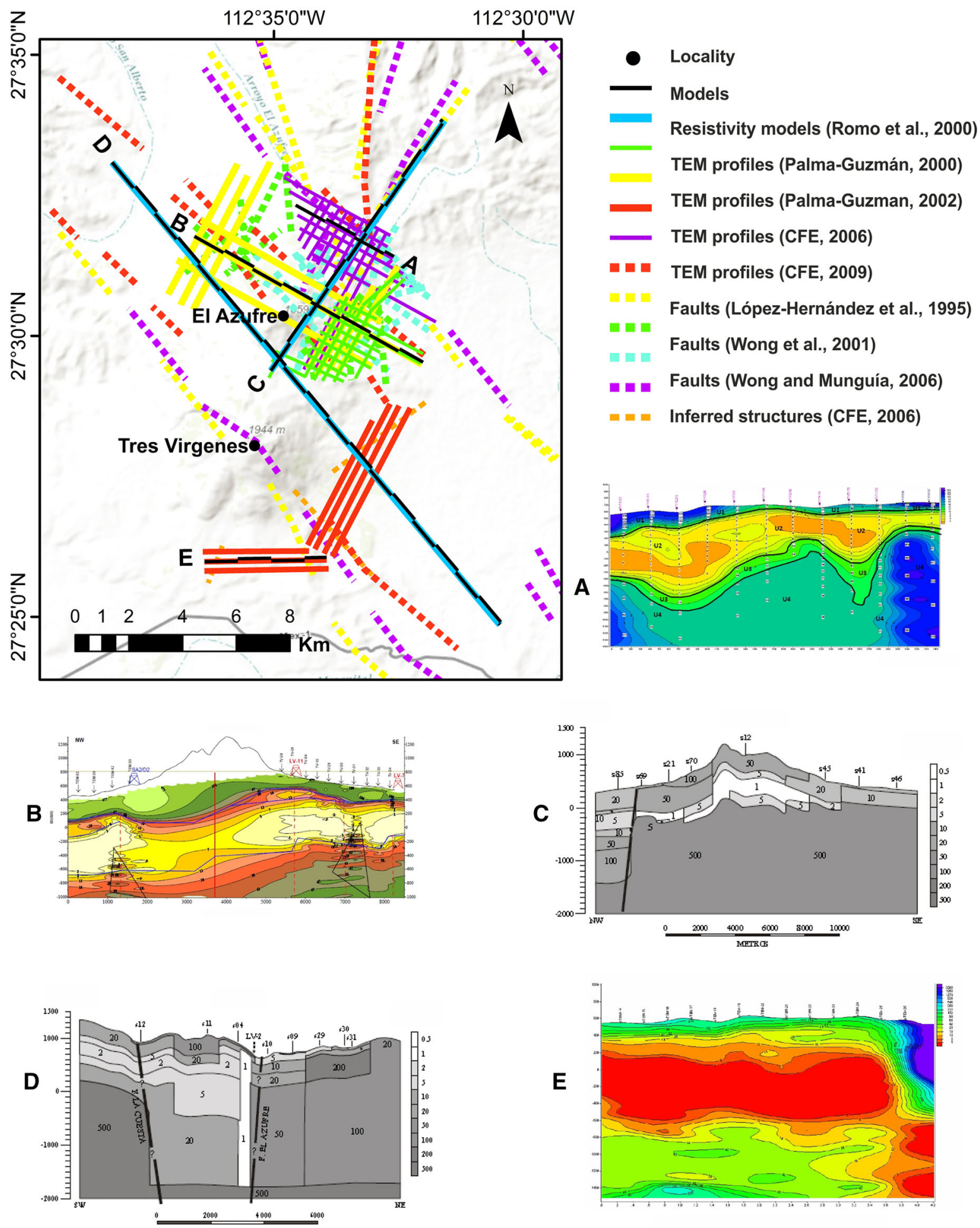

Figure 5. Geophysical surveys in the LTVGF. Information from Palma-Guzmán (2000, 2002); CFE (2006, 2009); López-Hernández et al. (1995); Romo et al. (2000); Wong et al. (2001); Wong and Munguía (2006). 
The recovery factor for a fractured reservoir, as the LTVGF, is estimated to be in the range from 0.05 to 0.20 (Williams 2014).

Based on the analysis by Zarrouk and Moon (2014), the utilization efficiency of the plants installed in the Las Tres Virgenes geothermal field can be estimated as $13 \%$ from the mass output of 265 $(\mathrm{t} / \mathrm{h})$ with an enthalpy of $1188 \mathrm{~kJ} / \mathrm{kg}$. The average capacity factor for the year 2011 was $50 \%$ according to Flores-Armenta (2012) and 56\% in 2013 (FloresArmenta et al. 2014).

\section{APPLICATION OF THE VOLUMETRIC METHOD TO THE CPGF AND THE LTVGF}

The long exploitation history of the CPGF allows assignment of more realistic values for parameters like: thermal recovery factor, conversion efficiency, and load factor that will allow a reliable estimation of the energy potential for the next 30 years.

The LTVGF presents additional challenges for exploitation as low permeability, lack of recharge ,and intense scaling. However, evaluation of the potential is important to assess the expected relation investment risk versus revenue.
Calculations for the reservoir potential are performed using the method described in "Geothermal Resource Assessment" section for a plant life of 30 years assuming the present temperature and the estimated range for the reservoir area and thickness based on geophysics and well data to determine the volume of the reservoir but considering the present efficiency and load factor of the installed plants (Table 3). The input data for the calculation are those presented in Table 2, which were produced based on our rigorous analysis of the compiled information ("Cerro Prieto Geothermal Field (CPGF)" and "Las Tres Vírgenes Geothermal Field (LVTGF)" sections). Temperature ranges are obtained from well measurements and reservoir volumes are constrained by geophysical and well data, especially permeability to define the production zone. Calculations of the volumetric heat contained in the reservoir were performed for the parameter value ranges indicated in Table 2 using the Monte Carlo method. The results are presented in Table 3 for three probability values: 10,50 , and $90 \%$.

The results indicate that more than $1000 \mathrm{MWe}$ could be produced in CPGF at $50 \%$ probability for the present load factor of $78 \%$. However, if the load factor could be increased to $90 \%$, then production could increase to more than $100 \mathrm{MWe}$. The volu-

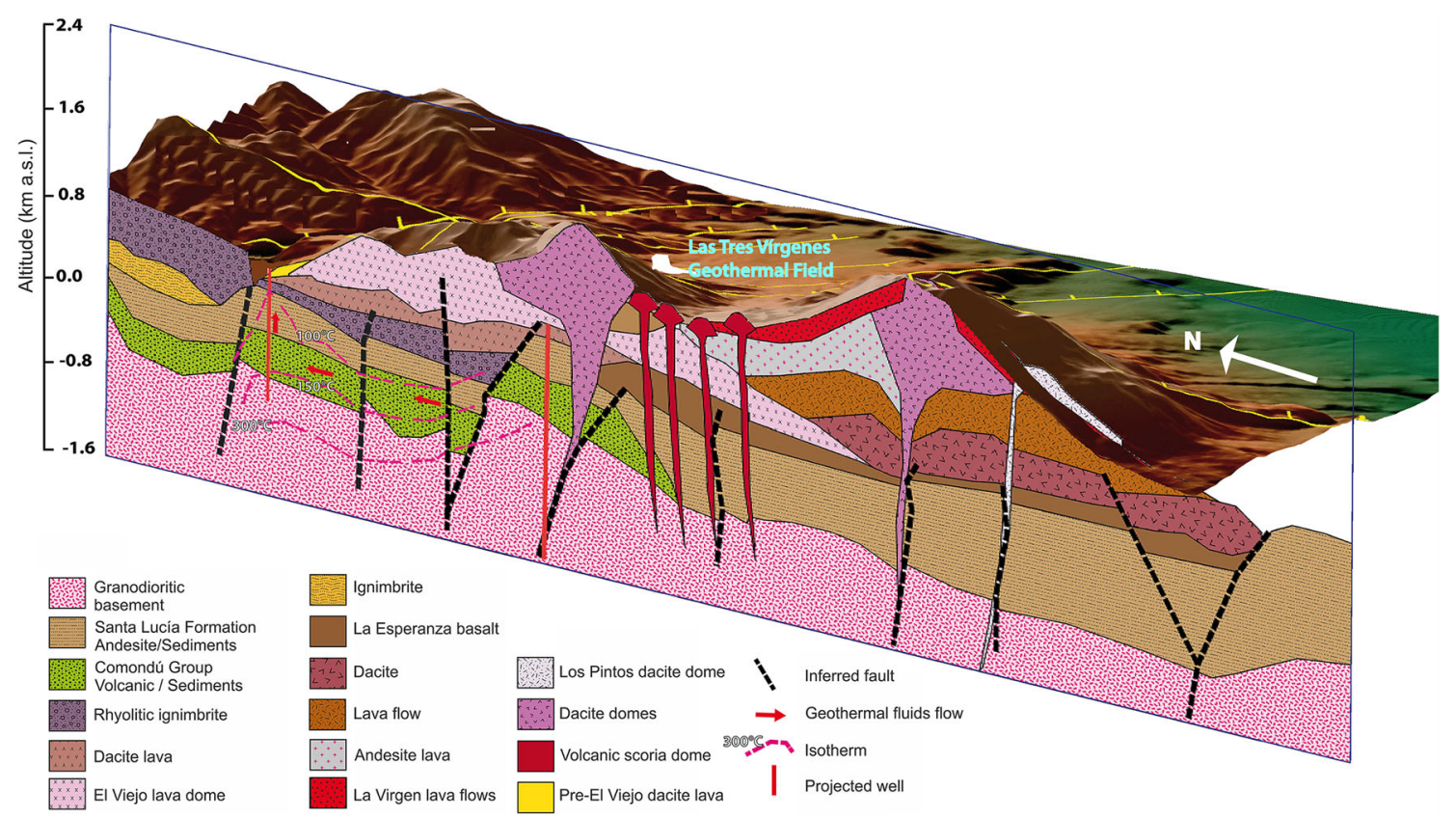

Figure 6. Conceptual model of the LTVGF (after López-Hernández et al. 1995; Macías-Vázquez and Jiménez-Salgado 2013). 
Table 3. Results of the Monte Carlo Simulations to Evaluate the Energy Potential of the Cerro Prieto and the Las Tres Vírgenes Geothermal Fields

\begin{tabular}{lccrr}
\hline & & $\begin{array}{c}\text { Cerro Prieto } \\
\text { (Beta Reservoir) }\end{array}$ & $\begin{array}{c}\text { Cerro Prieto } \\
\text { (Gamma Reservoir-Minimum) }\end{array}$ & Virgenes \\
\hline MWe capacity & $90 \%$ & 411 & 88 & 2 \\
& $50 \%$ & 1397 & & 48 \\
& $10 \%$ & 3341 & 239 \\
\hline
\end{tabular}

Calculations were performed assuming the present utilization efficiency and load factor: 49.3 and $78 \%$ for Cerro Prieto, and 13 and $56 \%$ for the Las Tres Vírgenes.

metric calculation for the LTVGF field shows that it is possible to increase production up to $48 \mathrm{MWe}$ at $50 \%$ probability, even with the load factor of $56 \%$ of the present exploitation scheme.

The results demonstrate that the potential of both fields is promising since the calculated available energy is $>1000$ MWe for both fields with the present exploitation schemes, and further increase in efficiency and plant factor would allow a larger expansion of electricity production.

\section{SUMMARY}

The reported data from the Cerro Prieto and Las Tres Virgenes geothermal fields, and our analysis of these data, provide enough information to estimate more accurately the reservoir parameters required to calculate the probable maximum energy potential. In both cases, the results support expectations of possible expansion of the fields, which might reach more than double the present production. In addition, further expansion of the electricity production can also be achieved by installing a more efficient plant setting with a higher plant factor.

\section{ACKNOWLEDGMENTS}

We thank Marcela Errasti-Orozco, Alejandra Membrillo, Ulises Valencia, Manuel Arrubarrena, Diego Ruíz-Aguilar, and Ruth Villanueva for their assistance in information collection and data processing. This work was supported by Project SENER-CONACyT Fondo de Sustentabilidad No.152823 "Evaluación de los recursos geotérmicos de la Península de Baja California: continentales, costeros y submarinos". We also thank Gerencia de Proyectos Geotermoeléctricos-CFE for supporting this project and providing information on geothermal areas in the Baja California Peninsula.

\section{OPEN ACCESS}

This article is distributed under the terms of the Creative Commons Attribution 4.0 International License (http://creativecommons.org/licenses/by/4.0/), which permits unrestricted use, distribution, and re production in any medium, provided you give appro priate credit to the original author(s) and the source, provide a link to the Creative Commons license, and indicate if changes were made.

\section{REFERENCES}

AGEA-AGEG (2010). Australian Code for Reporting of Exploration Results, Geothermal Resources and Geothermal Reserves. In The Geothermal Reporting Code (2nd Eds.).

Alonso, H. (1975). Potencial Geotérmico de la República Mexicana. In Second United Nations Symposium on the Development and use of Geothermal Resources (Vol. 1, pp. 17-24).

Alonso, H. (1985). Present and planned utilization of geothermal resources in México. International Symposium on Geothermal Energy. Geothermal Resources Council Transactions, 9, 135-140.

Antunez, E.U., Menzies, A.J., \& Sanyal, S.K. (1991). Simulating a challenging water dominated geothermal system: The Cerro Prieto Field, Baja California, Mexico. In Proceedings Sixteenth Workshop on Geothermal Reservoir Engineering Stanford University, Stanford, California, January 23-25. 1991 SGP-TR-134.

Arango-Galván, C., Prol-Ledesma, R. M., \& Torres-Vera, M. A. (2015). Geothermal prospects in the Baja California Peninsula. Geothermics, 55, 39-57.

Barragán, R.M., Iglesias, E.R., Arellano, V.M., Torres, R.J., Tapia, R., et al. (2010). Chemical Modeling of Fluids from the Las Tres Vírgenes B. C. S. (México) Geothermal Field. In Proceedings World Geothermal Congress 2010, Bali, Indonesia. 25-29 April.

Birkle, P., Portugal, M.E., \& Barragán, R.M. (2010). ChemicalIsotopic evidences for the origin and evolution of geothermal fluids at the Las Tres Vírgenes Geothermal Field, B.C., NWMéxico. In Proceedings World Geothermal Congress. BaliIndonesia, 25-29 April, 2010. 
Bodvarsson, G., \& Bolton, R.S. (1971). A study of the Ahuachapán geothermal field. U.N.D.P. In Survey of Geothermal Resources, El Salvador, May 1971.

Butler, S.J., Sanyal, S.K., Henneberger, R.C., Klein, C.W., et al. (2000). Numerical Modeling of the Cerro Prieto Geothermal Field, Mexico. In Proceedings World Geothermal Congress 2000, Kyushu-Tohoku, Japan, May 28-June 10, 2000.

Castañeda, M., Márquez, R., Arellano, V., \& Esquer, C.A. (1983). Reservoir Simulation on the Cerro Prieto Geothermal Field: A continuing study. In Proceedings Ninth Workshop Geothermal Reservoir Engineering. Stanford University, Stanford, California, December 1983. SGP-TR-74-48.

Castillo, F., Bermejo, F.J., Domínguez, B., Esquer, C. A., \& Navarro, F.J. (1981). Temperature Distribution in the Cerro Prieto Geothermal Field. In Proceedings of the 3rd Symposium on the Cerro Prieto Geothermal Field, Baja California, Mexico. United States Department of Energy and Comisión Federal de Electricidad. March 24-26, San Francisco CA.

CFE (1984). Alternativas de pozos exploratorios en Cerro Prieto, valle de Mexicali y Laguna Salada, B.C. Gerencia de Estudios Geotermoeléctricos, Departamento de Exploración, CFE. Reporte 1/84.

CFE (2006). Estudio de resistividad con Transitorio Electromagnético en el campo geotérmico Las Tres Vírgenes, B.C.S. (zona sur). Gerencia de Estudios Geotermoeléctricos, Departamento de Exploración, CFE. Reporte GF-TV-RE-0306.

CFE (2009). Estudio de resistividad electromagnética en zonas geotérmicas del noroeste de México (Norte del Volcán Partido en C. G. Las tres Vírgenes, B.C.S.). Gerencia de Estudios Geotermoeléctricos, Departamento de Exploración, CFE. Reporte DEX-DGF-TKTVPL-10-09.

Cobo, J.M. (1979). Geología y mineralogía del campo geotérmico de Cerro Prieto. In Proceedings of the. 2nd Symposium on the Cerro Prieto Geothermal Field, Mexicali, BC, Mexico, 17-19 October (pp. 103-117). Comisión Federal de Electricidad.

CONAGUA (2011). Determinación de la disponibilidad de agua en el acuífero 0338 Las Vírgenes, Estado de Baja California Sur, Comisión Nacional del Agua, Subdirección General Técnica, Gerencia de aguas subterráneas.

Contreras, E., \& García, P. (1998). Mediciones petrofísicas en muestras de los fragmentos de núcleos de perforación $L V-5$, $L V-8 A$ y $L V-8 B$. Instituto de Investigaciones Eléctricas, Mexico. Internal report, Contract No. GPG/LIR/CPS/006/98.

Cruz-Castillo, M. (2002). Catálogo de las fallas regionales activas en el norte de la Baja California, México. Geos, 22(1), 37-42.

De Boer, J. (1980). Paleomagnetism of the Quaternary Cerro Prieto, Crater Elegante, and Salton Buttes Volcanic Domes in the Northern Part of the Gulf of California Rhombochasm. In Proceedings of the 2th Symposium on the Cerro Prieto Geothermal Field.

Díaz, S., \& Arellano, J.F. (1979). Estudio de resistividad y potencial espontáneo en la parte sur del Valle de Mexicali, B.C.N. Gerencia de Estudios Geotermoeléctricos, Departamento de Exploración, CFE. Reporte 9-79.

DiPippo, R. (2012). Geothermal power plants: Principles, applications, case studies and environmental impact. Amsterdam: Butterworth-Heinemann.

DOE-CFE (1982). Minutes of the Second Cerro Prieto Internal DOE/CFE Workshop, Hotel Fiesta, San Felipe, B.C., Mexico, January 19-21, 1982.

Flores, C., \& Velasco, N. (1998). A comparative analysis between transient electromagnetic soundings and resistivity soundings in the Tres Virgenes geothermal zone, Mexico. Geofísica Internacional, 37, 183-199.

Flores-Armenta, M. (2012). Geothermal activity and development in Mexico-keeping the production going. In Short course on geothermal development and geothermal wells, March 11-17, 2012. Santa Tecla, El Salvador: UNU-GTP and LaGeo.
Flores-Armenta, M., \& Jaimes-Maldonado, G. (2001). The Las Tres Virgenes Mexico geothermal reservoir. Geothermal Resources Council Transactions, 25, 525-534.

Flores-Armenta, M., Ramírez-Montes, M., \& Morales-Alcalá, L. (2014). Geothermal activity and development in Mexicokeeping the production going. Paper presented at "Short Course VI on Utilization of Low- and Medium-Enthalpy Geothermal Resources and Financial Aspects of Utilization", organized by UNU-GTP and LaGeo, in Santa Tecla, El Salvador, March 23-29, 2014.

García, A., Ascencio, F., Espinosa, G., Santoyo, E., Gutiérrez, H., et al. (1999). Numerical modeling of high-temperature deep wells in the Cerro Prieto geothermal field, Mexico. Geofísica Internacional, 38(4), 251-260.

García-Cruz, C., \& Ramírez, M. (2000). Development of Las Tres Vírgenes geothermal project. Geothermal Resources Council Bulletin, 23, 59-63.

Garg, S.K., \& Combs, J. (2010). Appropriate use of USGS volumetric "heat in place" method and Monte Carlo calculations. In Thirtyfourth workshop on geothermal reservoir engineering Stanford University, Stanford, California. February 1-3, 2010. SGP-TR-188.

Garg, S. K., \& Combs, J. (2015). A reformulation of USGS volumetric "heat in place" resource estimation method. Geothermics, 55, 150-158.

González, M., \& Munguía, L. (2003). Seismic anisotropy observations in the Mexicali Valley, Baja California, México. Pure and Applied Geophysics, 160(12), 2257-2278.

Grant, M.A., Truesdell, A.H., \& Mañón, M. (1981). Production induced boiling and cold water entry in the Cerro Prieto geothermal reservoir indicated by chemical and physical measurements. In 3rd Symposium on the Cerro Prieto Geothermal Field, Baja California, Mexico. United States Department of Energy and Comisión Federal de Electricidad. March, 24-26, San Francisco CA.

Gutiérrez-Negrín, L. C. A. (2012). Update of the geothermal electric potential in Mexico. Geothermal Resources Council Transactions, 36, 671-677.

Gutiérrez-Puente, H., \& Rodríguez, M.H. (2000). 28 Years of Production at Cerro Prieto Geothermal Field. Proceedings World Geothermal Congress 2000, Kyushu-Tohoku, Japan, May 28-June 10, 2000.

Halfman, S. E., Lippmann, M. J., Zelwer, R., \& Howard, J. H. (1984). Geologic interpretation of geothermal fluid movement in Cerro Prieto Field, Baja California, Mexico. AAPG Bulletin, 68, 18-30.

Hiriart, G., Gutiérrez Negrín, L.C.A., Quijano León, J.L., Ornelas Celis, A., Espíndola, S., et al. (2011). Evaluación de la Energía Geotérmica en México. In Informe para el Banco Interamericano de Desarrollo y la Comisión Reguladora de Energía.

Iglesias, E. R., \& Torres, R. J. (2003). Low- to medium-temperature geothermal reserves in Mexico: A first assessment. Geothermics, 32, 711-719.

Iglesias, E. R., \& Torres, R. J. (2009). Primera estimación de las reservas geotérmicas de temperatura intermedia a baja en veinte estados de México. Geotermia, 22(2), 54-65.

Izquierdo, G., Portugal, E., Aragón, A., Torres, I., \& Alvarez, H. (2001). Hydrothermal mineralogy, isotopy and geochemistry in area of the Cerro Prieto IV Baja California Norte, Mexico. Geothermal Resources Council Transactions, 25, 353-356.

Lippmann, M.J., Truesdell, A.H., \& Gutiérrez-Puente, H. (1997). What will a $6 \mathrm{Km}$ deep well at Cerro Prieto find? In 21st workshop on geothermal reservoir engineering Stanford University, Stanford, California. January 27-29, 1997. SGP-TR-155.

Lippmann, M. J., Truesdell, A. H., Halfman-Dooley, S. E., \& Mañón, M. A. (1991). A review of the hydrogeologic-geochemical model for Cerro Prieto. Geothermics, 20, 39-52.

Lippmann, M. J., Truesdell, A. H., Rodríguez, M. H., \& Pérez, A. (2004). Response of Cerro Prieto II and III (Mexico) to exploitation. Geothermics, 33, 229-256. 
Lira, H. (2005). Actualización del modelo geológico conceptual del yacimiento geotérmico de Cerro Prieto, B.C. Geotermia, 18(1), 37-46.

López-Hernández, A., Casarrubias-Unzueta, Z., \& Leal, H.R. (1993). Estudio Geológico regional de la zona geotérmica de Las Tres Virgenes, B.C.S. C.F.E.- Gerencia de Proyectos Geotermoeléctricos. México.

López-Hernández, A., García, G., \& Arellano, F. (1995). Geothermal exploration at Las Tres Vírgenes, B.C.S. In Proceedings World Geothermal Congress 1995. Florence, Italy, April 1995.

López-Hernández, A., Robin, C., Cantagrel, J. M., \& Vincent, P. (1989). Estudio geoquímico, mineralógico y edades radiométricas de la zona de Tres Vírgenes, B.C.S. Implicaciones geotérmicas. C.F.E.-Gerencia de Proyectos Geotermoeléctricos, Internal Report 5/89, $50 \mathrm{p}$.

Macías-Vázquez, J. L., \& Jiménez-Salgado, E. (2013). Estudio de Estratigrafía y Geología del complejo volcánico Tres Vírgenes, B.C.S. Geotermia, 26(1), 14-23.

McNitt, J. R. (1978). The United Nations' approach to geothermal resource assessment. Geothermics, 7, 231-242.

Mercado, S. (1976). The geothermal potential evaluation of Mexico by geothermal chemistry. In Proceedings of the International Congress on Thermal Waters, Geothermal Energy and Volcanism of the Mediterranean Area, Atenas, Grecia.

Mercado, S., Arellano, V.M., Barragán, R.M., Hurtado, R., Nieva, et al. (1982). Diagnósticos y Pronósticos Sobre los Aspectos Científicos y Tecnológicos de la Geotermia como Fuente de Energía en México. Informe IIE/CFE-G37/1767/3.

Mercado, S., Siqueiros, J., \& Fernández, H. (1985). Low enthalpy geothermal reservoirs in Mexico and Field experimentation on binary-cycle systems. Geothermal Resources Council Transactions, 9, 523-526.

Muffler, L.P.J. (1979). Assessment of geothermal resources of the United States-1978 (Vol. 790). U.S.G.S. Circular.

Muffler, P., \& Cataldi, R. (1978). Methods for regional assessment of geothermal resources. Geothermics, 7, 53-89.

Ordaz-Méndez, C. A., Flores-Armenta, M., \& Ramírez-Silva, G. (2011). Potencial geotérmico de la República Mexicana. Geotermia, 24(1), 50-58.

Palma-Guzmán, S.H. (2000). Comentarios sobre el studio de resistividad con transiente electromagnettico en el campo geotérmico de las Tres Vírgenes, BCS. Gerencia de Estudios Geotermoeléctricos, Departamento de Exploración, CFE. Reporte GF/TV/04/2000.

Palma-Guzmán, S.H. (2002). Integración de los estudios de Transitorio Electromagnético en el campo geotérmico de Tres Vírgenes, B.C.S. Gerencia de Estudios Geotermoeléctricos, Departamento de Exploración, CFE. Reporte GF/TV/12/ 2002.

Portugal, E., Birkle, P., Barragán, R. R. M., Arellano, G. V. M., Tello, E., et al. (2000). Hydrochemical-isotopic and hydrogeological conceptual model of the Las Tres Virgenes geothermal field, Baja California Sur, México. Journal of Volcanology and Geothermal Research, 101, 223-244.

Portugal, E., Izquierdo, G., Barragán, R.M., \& de León V., J. (2005b). Reservoir Processes Inferred by Geochemical, Stable Isotopes and Gas Equilibrium Data in Cerro Prieto, B.C., México. In Proceedings World Geothermal Congress 2005, Antalya, Turkey, April 24-29, 2005.

Portugal, E., Izquierdo, G., Truesdell, A., \& Álvarez, J. (2005a). The geochemistry and isotope hydrology of the Southern Mexicali Valley in the area of the Cerro Prieto, Baja California (Mexico) geothermal field. Journal of Hydrology, 313, 132-148.

Puente, C., \& De-La-Peña, A. (1979). Geology of the Cerro Prieto geothermal field. Geothermics, 8, 155-175.

Quintanilla-Montoya, A. L., \& Suárez-Vidal, F. (1996). Cerro Prieto and its relation to the Gulf of California Spreading Centers. Ciencias Marinas, 22(1), 91-110.
Razo, A., \& Arellano, F. (1978). Prospección eléctrica de la porción norte del valle de Mexicali y campo geotérmico de Cerro Prieto, Baja California. Gerencia de Estudios Geotermoeléctricos, CFE. Reporte 6-78.

Razo, A., \& Fonseca, H. (1978). Prospección gravimétrica y magnetómetrica en el valle de Mexicali, B. C. Gerencia de Estudios Geotermoeléctricos, CFE. Reporte 5-78.

Razo Montiel, A. (1984). Estudios geológicos, geofísicos y geoquímicos de la zona geotérmica Las Tres Vírgenes, B.C.S. Gerencia de Estudios Geotermoeléctricos, Departamento de Exploración, CFE. Reporte DEX 3/84.

Romo, J.M., Wong, V., Flores, C., \& Vázquez, R. (2000). The subsurface electrical conductivity and the attenuation of coda waves at Las Tres Vírgenes geothermal field in Baja California Sur, México. In Proceedings World Geothermal Congress 2000.

Suárez-Vidal, F., Mendoza-Borunda, R., Nafarrete-Zamarripa, L. M., Ramírez, J., \& Glowacka, E. (2008). Shape and dimensions of the Cerro Prieto pull-apart basin, Mexicali, Baja California, Mexico, based on the regional seismic record and surface structures. International Geology Review, 50(7), 636-649.

Tello, E., Verma, M.P., \& González-Partida, E. (2005). Geochemical characteristics of reservoir fluids in the Las Tres Virgenes, BCS, Mexico. In Proceedings World Geothermal Congress 2005, Antalya, Turkey.

Tello-López, M.R., \& Torres-Rodríguez, M.A. (2015). Behavior of the production characteristics of the wells in the Las Tres Vírgenes, B. C. S., Geothermal Field, México. In Proceedings World Geothermal Congress 2015, Melbourne, Australia, April 19-25, 2015.

Torres-Rodríguez, M. A., \& Sánchez-Velasco, R. A. (1995). Development of the Las Tres Virgenes geothermal field, Mexico. Geothermal Resources Council Transactions, 19, 417-423.

Turner, W.J. (1969). A reservoir engineering study of Ahuachapan geothermal reservoir for feasibility of sub-surface disposal of hot saline water. Internal Project Report.

van Wees, J.D., Boxem, T., Calcagno, P., Dezayes, C., Lacasse, C., et al. (2013). A Methodology for Resource assessment and application to core countries. GEOELEC, Deliverable $\mathrm{n}^{\circ} 2.1$.

Viggiano-Guerra, J. C., Sandoval-Medina, F., Flores-Armenta, R. J., Pérez, R. J., \& González-Partida, E. (2009). Aplicación del SPCACL en la especiación química y termodinámica de fluidos: ejemplo del caso de los pozos LV-4A, LV-11 y LV13, del campo geotérmico de Las Tres Virgenes, BCS. Geotermia, 22(1), 12-27.

Williams, C. (2014). Evaluating the volume method in the assessment of identified geothermal resources. Geothermal Resources Council Transactions, 38, 967-974.

Williams, C.F., Reed, M.J., \& Mariner, R.H. (2008). A Review of methods applied by the U.S. Geological Survey in the assessment of identified geothermal resources, U.S. Department of the Interior, U.S. Geological Survey, Open-File Report 20081296, $27 \mathrm{p}$.

Wilt, M., Goldstein, E., \& Sasaki, Y. (1984), Long-term dipoledipole resistivity monitoring at the Cerro Prieto geothermal field. In Geothermal resources council 1984 annual meeting, Reno, NV, August 26-29, 1984. DE84 012251. LBL-17644.

Wong, V., \& Munguía, L. (2006). Seismicity, focal mechanisms, and stress distribution in the Tres Vírgenes volcanic and geothermal region, Baja California Sur, Mexico. Geofísica Internacional, 45(1), 23-37.

Wong, V., Rebollar, C. J., \& Munguía, L. (2001). Attenuation of coda waves at the Tres Vírgenes volcanic area, Baja California Sur, México. Bulletin of the Seismological Society of America, 91, 683-693.

Zarrouk, S. J., \& Moon, H. (2014). Efficiency of geothermal power plants: A worldwide review. Geothermics, 51, 142-153. 